*akls View/Frint Document Cover Sheet tow

This document was retrieved from the Boeing ISEARCH System.

Accession \#: D196054637

Document \#: SD-WM-ER-440

Title/Desc:

TANK 241BY111 HEADSPACE GAS \& VAPOR CHARACTERIZATION RESULTS FOR SAMPLES COLLECTED IN $5 / 1994 \& 11 / 1994$ 


\section{ENGINEERING CHANGE NOTICE}

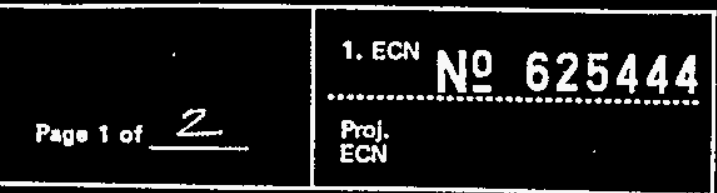

\begin{tabular}{|c|c|c|c|c|c|}
\hline \multirow{3}{*}{$\begin{array}{l}\text { 2. ECN Category } \\
\text { (mark one) } \\
\text { Supplemental } \\
\text { Direct Revision } \\
\text { Change ECN } \\
\text { Temporary } \\
\text { Standby } \\
\text { Supersedure }\end{array}$} & \multicolumn{2}{|c|}{$\begin{array}{l}\text { 3. Originator's Name, organization, MSIN, } \\
\text { and Telephone No. } \\
\text { D. R. BRATZEL, 75640, S7-21, } \\
\text { 373-3579 }\end{array}$} & \multicolumn{2}{|c|}{$\begin{array}{l}\text { 3a. UsQ Required? } \\
{[] \text { Yes }[X] \text { No }}\end{array}$} & $\begin{array}{l}\text { 4. Date } \\
09 / 27 / 95\end{array}$ \\
\hline & \multicolumn{2}{|c|}{$\begin{array}{l}\text { 5. Project Title/No./Work order No. } \\
\text { TANK 241-BY-111 HEADSPACE GAS } \\
\text { AND VAPOR CHARACTERIZATION } \\
\text { RESULTS FOR SAMPLES COLLECTED } \\
\text { IN MAY } 1994 \text { AND NOVEMBER } 1994\end{array}$} & \multicolumn{2}{|c|}{$\begin{array}{l}\text { 6. Bldg./Sys./Fac. No. } \\
2704 \mathrm{HV} / 200 \mathrm{E}\end{array}$} & $\begin{array}{l}\text { 7. Approval Designator } \\
\text { N/A }\end{array}$ \\
\hline & \multicolumn{2}{|c|}{$\begin{array}{l}\text { 8. Document Numbers Changed by this ECN } \\
\text { (includes sheet no. and rev.) } \\
\text { WHC-SD-WM-ER-440 REV } X 0^{\% / 2} \% \text {. }\end{array}$} & \multicolumn{2}{|c|}{$\begin{array}{l}\text { 9. Related ECN No(s). } \\
\text { N/A }\end{array}$} & $\begin{array}{l}\text { 10. Related Po No. } \\
\text { N/A }\end{array}$ \\
\hline $\begin{array}{l}\text { 11a. Modification Work } \\
\text { [] Yes (fill out Blk. } \\
11 b \text { ) } \\
{[X] \text { No (NA Blks. 11b, }} \\
11 c, 11 d \text { ) }\end{array}$ & $\begin{array}{l}\text { 11b. Work Package } \\
\text { No. } \\
\text { N/A }\end{array}$ & \multicolumn{2}{|c|}{$\begin{array}{l}\text { 11c. Modification Work Complete } \\
\text { N/A } \\
\text { Cog. Engineer Signature \& Date }\end{array}$} & \multicolumn{2}{|c|}{$\begin{array}{l}\text { 11d. Restored to Original Condi- } \\
\text { tion (Temp. or Standiby ECN only) } \\
\text { N/A }\end{array}$} \\
\hline \multicolumn{6}{|c|}{$\begin{array}{l}\text { 12. Description of change } \\
\text { Title change and complete rewrite. }\end{array}$} \\
\hline \multicolumn{6}{|c|}{$\begin{array}{l}\text { 13a. Justification (mark one) } \\
\text { Criteria Change }[X] \quad \text { Design Improvement }\end{array}$} \\
\hline \multirow{2}{*}{\multicolumn{6}{|c|}{$\begin{array}{l}\text { 13b. Justification Details } \\
\text { Complete rewrite which includes all vapor sampling events to date and data } \\
\text { qualification. }\end{array}$}} \\
\hline & & & & & \\
\hline \multirow{2}{*}{\multicolumn{4}{|c|}{$\begin{array}{l}\text { 14. Distribution (include name, MSIN, and no. of copies) } \\
\text { See attached Distribution Sheet }\end{array}$}} & \multicolumn{2}{|r|}{ RELEASE STAMP } \\
\hline & & & & \multicolumn{2}{|c|}{$\begin{array}{l}\text { OFFICIAI. FIELEASE } \\
\text { BYWHC } \\
\text { DATE SEP } 281995\end{array}$} \\
\hline
\end{tabular}




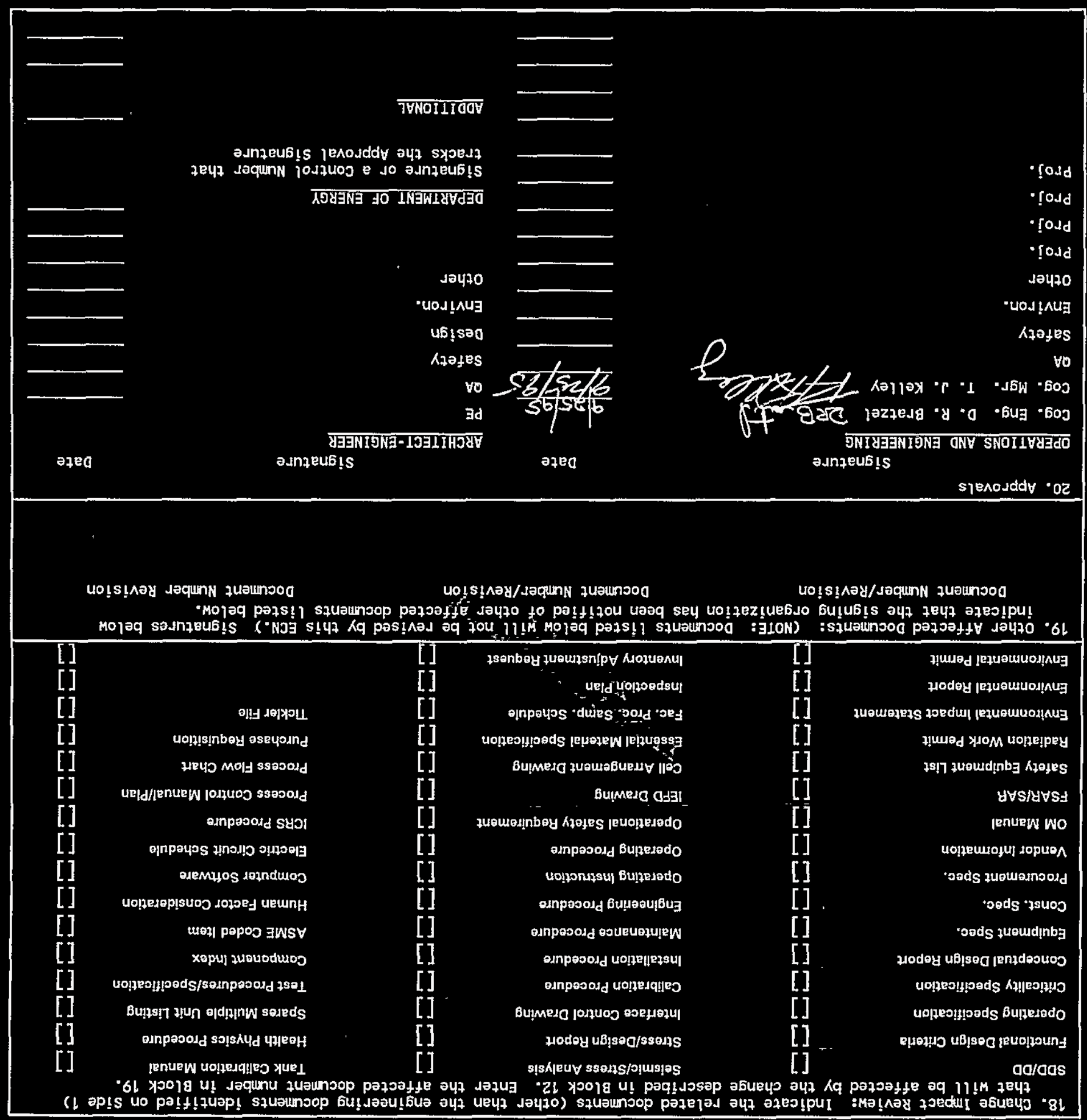

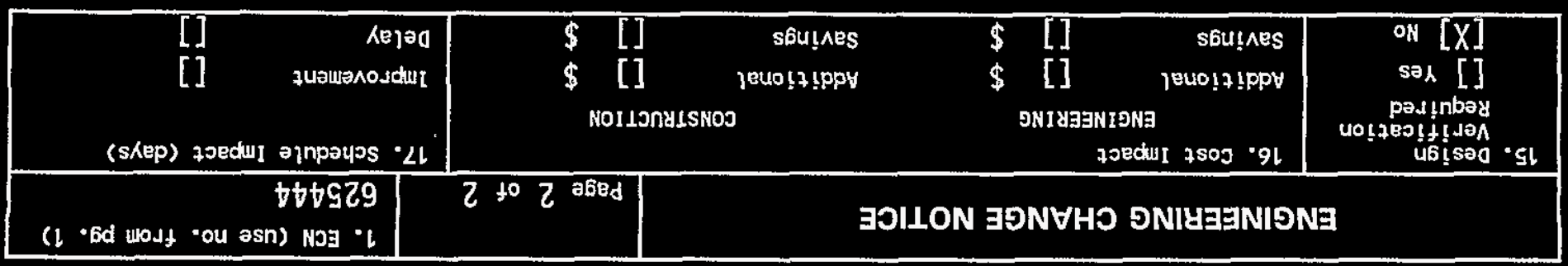




\section{RELEASE AUTHORIZATION}

Document Number: $\quad$ WHC-SD-WM-ER-440, REV 1

Document Title: Tank 241-BY-111 Headspace Gas and Vapor

Characterization Results for Samples Collected in

May 1994 and November 1994

Release Date: $\quad 9 / 28 / 95$

This document was reviewed following the procedures described in WHC-CM-3-4 and is:

APPROVED FOR PUBLIC RELEASE

WHC Information Release Administration Specialist:
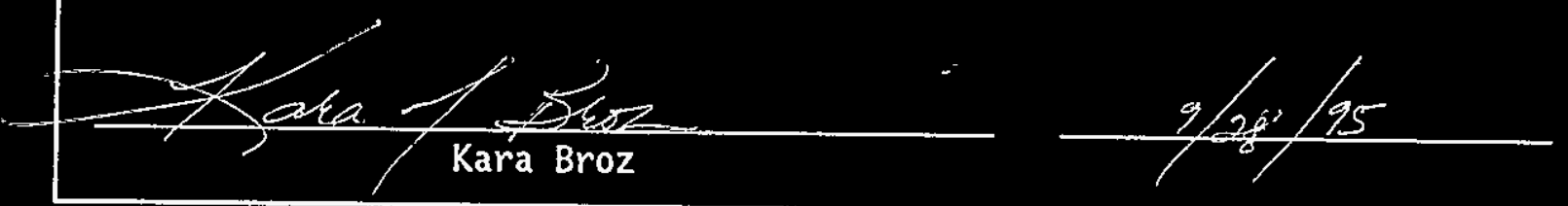

TRADEMARK DISCLAIMER. Reference herein to any specific commercial product, process, or service by trade name, trademark, manufacturer, or otherwise, does not necessarily constitute or imply its endorsement, recommendation, or favoring by the United States Government or any agency thereof or its contractors or subcontractors.

This report has been reproduced from the best available copy. Available in paper copy. Printed in the United States of America. To obtain copies of this report, contact:

Westinghouse Hanford Company - Document Control Services

P.0. Box 1970, Mailstop H6-08, Richland, WA 99352

Telephone: (509) 372-2420; Fax: (509) 376-4989 
2. Title

TANK 241-BY-111 HEADSPACE GAS AND VAPOR CHARACTERIZATION RESULTS FOR SAMPLES COLLECTED IN MAY 1994 AND NOVEMBER 1994

5. Key Words

CHARACTERIZATION OBJECTIVES, TANK HEADSPACE, SAMPLING EVENT, INORGANIC GASES, ORGANIC VAPORS
3. Nunber

WHC-SD-WM-ER-440

4. Rev No.

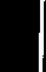

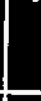

6. Author
Name: D. R. BRATZEL
signature $P R B+1$ a/25/as
Organization/Charge code $75640 /$ N4AB1

7. Abstract

Significant changes have been made to all of the original vapor characterization reports. This report documents specific headspace gas and vapor characterization results for all vapor sampling events to date. In addition, changes have been made to the original vapor reports to qualify the data based on quality assurance issues associated with the performing laboratories.

\begin{tabular}{l}
\hline. \\
OFFICIAL RELEASE \\
BYWHC \\
DATE SEP 2 \& 1095 \\
Sta 4
\end{tabular}




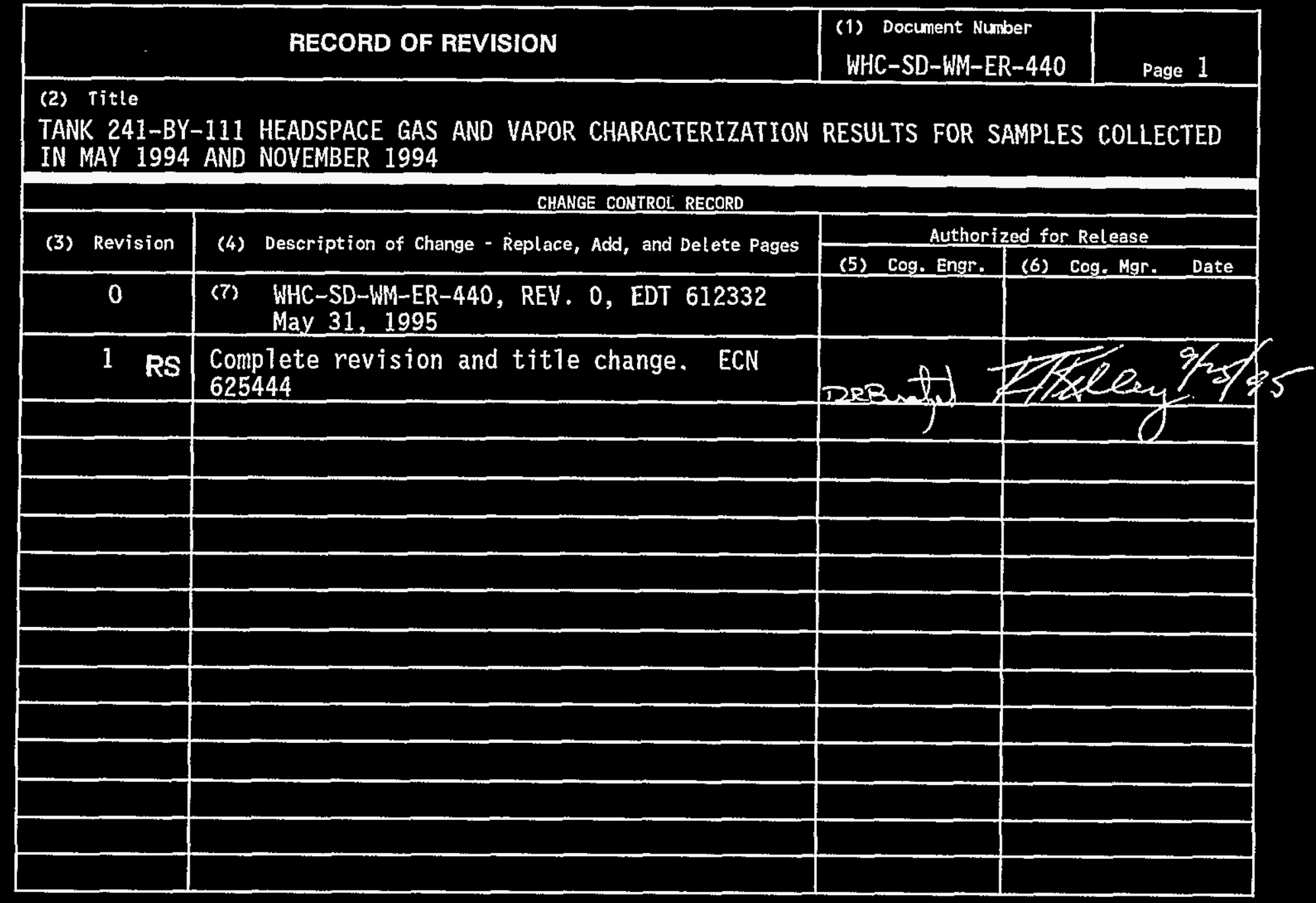




\title{
Tank 241-BY-111 Headspace Gas and Vapor Characterization Results for Samples Collected in May 1994 and November 1994
}

\author{
J. L. Fuckaby
}

Pacific Northwest Laboratories

D. R. Bratzel

Westinghouse Fanford Company

Date Published

September 1995

Prepared for the U.S. Department of Energy Office of Environmental Restoration and Waste Management 


\section{Contents}

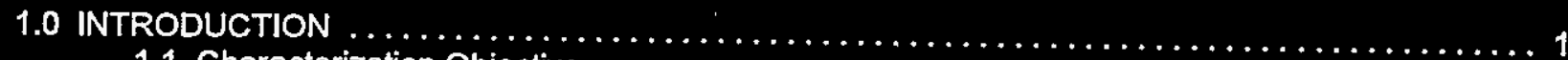

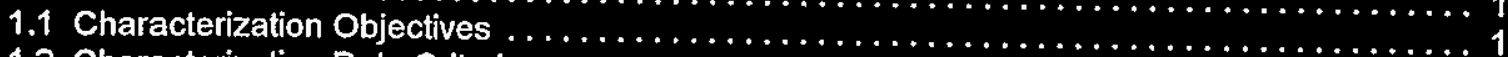

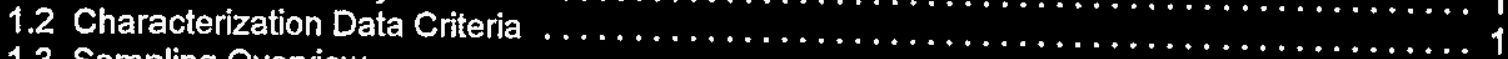

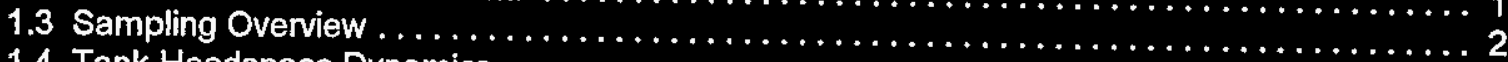

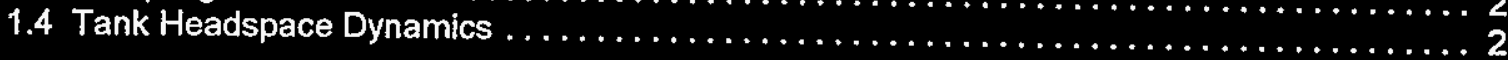

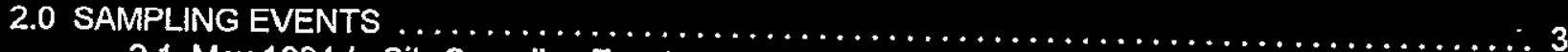

2.1 May 1994 In Situ Sampling Event $\ldots \ldots \ldots \ldots \ldots \ldots \ldots \ldots \ldots \ldots \ldots \ldots \ldots \ldots \ldots \ldots \ldots \ldots$

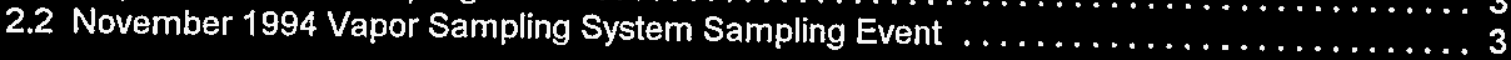

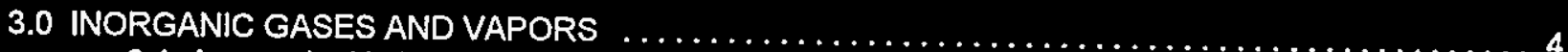

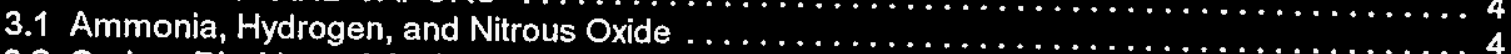

3.2 Carbon Dioxide and Carbon Monoxide $\ldots \ldots \ldots \ldots \ldots \ldots \ldots \ldots \ldots \ldots \ldots \ldots \ldots$

3.3 Nitric Oxide, Nitrogen Dioxide, Water and Tritium . . . . . . . . . . . . . . . . . . . . . 5

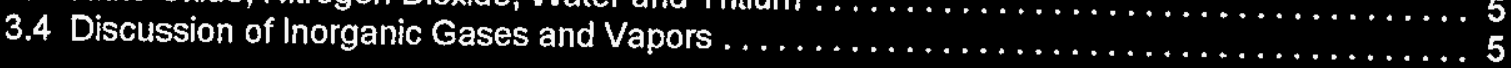

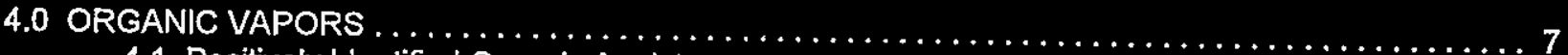

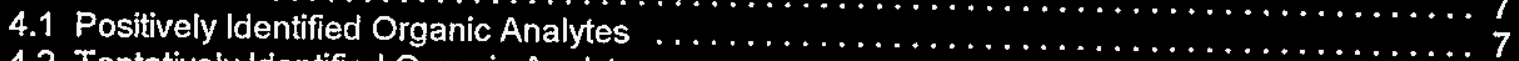

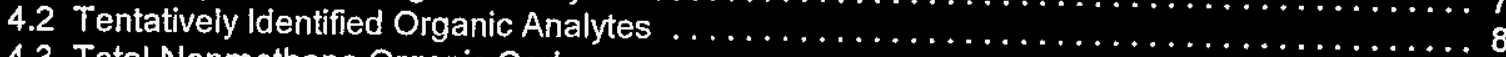

4.3 Total Nonmethane Organic Carbon $\ldots \ldots \ldots \ldots \ldots \ldots \ldots \ldots \ldots \ldots \ldots \ldots \ldots \ldots$

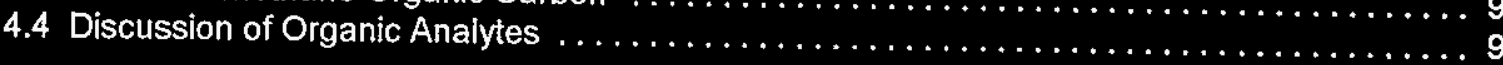

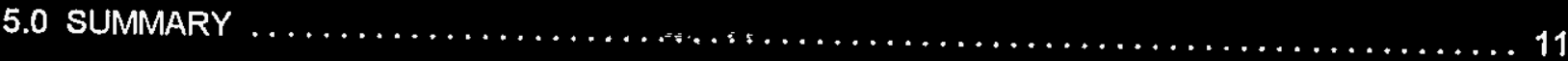

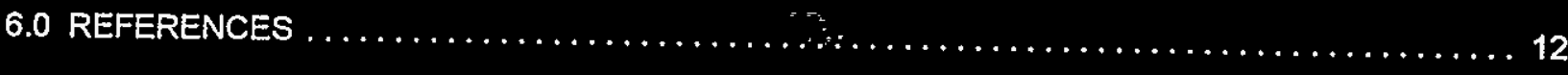

Acronyms and Abbreviations

$\begin{array}{ll}\text { CES } & \text { consensus exposure standard } \\ \text { EPA } & \text { Environmental Protection Agency } \\ \text { GC } & \text { gas chromatograph } \\ \text { GC/MS } & \text { gas chromatograph/mass spectrometer } \\ \text { ISS } & \text { in situ sampling } \\ \text { LFL } & \text { lower flammability limit } \\ \text { MS } & \text { mass spectrometer } \\ \text { NFPA } & \text { National Fire Protection Association } \\ \text { NPH } & \text { normal paraffinic hydrocarbon } \\ \text { OGIST } & \text { Oregon Graduate Institute of Science and Technology } \\ \text { ORNL } & \text { Oak Ridge National Laboratory } \\ \text { PNL } & \text { Pacific Northwest Laboratory } \\ \text { ppmv } & \text { parts per million by volume, } 1 \text { ppmv }=10^{-4} \text { vol\% } \\ \text { TST } & \text { triple sorbent trap } \\ \text { vol\% } & \text { percent by volume, } 1 \text { vol\% }=10,000 \mathrm{ppmv} \\ \text { VSS } & \text { vapor sampling system } \\ \text { WHC } & \text { Westinghouse Hanford Company }\end{array}$

Acknowledgements

The author wishes to thank Chris Simonen for her work verifying data and generating tables, and Shas Mattigod for his help with the construction and reviews of this document. 
WHC-SD-WM-ER-440 REV. 1

Tank 241-BY-111 Headspace Gas and Vapor Characterization Results

for Samples Collected in May 1994 and November 1994

\subsection{INTRODUCTION}

\subsection{Characterization Objectives}

Tank BY-111 headspace gas and vapor samples were collected and analyzed to help determine the potential risks of fugitive emissions to tank farm workers. The drivers and objectives of waste tank headspace sampling and analysis are discussed in Program Plan for the Resolution of Tank Vapor lssues (Osborne and Huckaby 1994). This report primarily discusses results from the November 1994 sampling event, but also includes selected results of the May 1994 sampling event. The tank BY-111 headspace was sampled in May 1994 in accordance with Safety Assessment for Gas Sampling All Ferrocyanide Tanks (Farley 1991), and in November 1994 in accordance with Data Quality Objectives for Generic In-Tank Health and Safety Issue Resolution (Osborne et al. 1994).

\subsection{Characterization Data Criteria}

Data Quality Objectives for Generic In-Tank Health and Safety Issue Resolution describes parameters for data collection to ensure appropriate conclusions can be drawn from the data. Tank headspace characterization data were collected to help in the evaluation of 1) headspace flammability, and 2) identification and quantification of compounds of toxicological concern.

Single Shell Tank Interim Operational Safety Requirements (Dougherty 1995) specifies that combustible constituents in tank headspaces be maintained below $25 \%$ of the lower flammability limit (LFL). This essentially agrees with National Fire Protection Association requirements that combustible concentrations be maintained at or below $25 \%$ of the LFL (NFPA 1992). Current governing operating specifications for Watchlist tanks, such as tank BY-111, specify that combustible constituents be maintained at or below $20 \%$ of the LFL (WHC 1995a).

Headspace characterization data are used by Westinghouse Hanford Company (WHC) Tank Waste Remediation Systems Industrial Hygiene as source term data in the industrial hygiene strategy to protect workers from tank fugitive emissions. Because selection of worker protective equipment must be based on industrial hygiene monitoring of the work place and not on source term data (29 CFR 1910.120), tank headspace characterization data can not be used for this purpose. Furthermore, because there are mechanisms by which headspace constituents can be either diluted or concentrated as they are released to the atmosphere, the headspace characterization data should not be considered to be representative of emissions at the point of emission.

These statements notwithstanding, the data quality objectives document specifies that the industrial hygiene group be advised if constituents with toxicological properties exceed $50 \%$ of the appropriate consensus exposure standard (CES) for non-carcinogens, or $10 \%$ of the appropriate CES for carcinogens. A CES is defined as the most stringent of known regulatory or recommended toxicological values for the workplace (Osborne et al. 1994). 


\subsection{Sampling Overview}

Tank BY 111 was vapor sampled in May 1994 using the in situ sampling (ISS) method, and again in November 1994 using the more robust vapor sampling system (VSS) method. Unfortunately, the ISS event sorbent trap samples were radiologically contaminated, and were never analyzed (Huckaby et al. 1995). Furthermore, there are discrepancies between results from the ISS and VSS methods that are not understood (Huckaby 1994a), and until the ISS method has been validated and the discrepancies resolved, results from early ISS events should be considered suspect.

Nevertheless, a brief description of the ISS event and the total nonmethane organic carbon (TNMOC) measurement from the May 1994 ISS event are presented below, because this analysis was not performed on samples from the VSS event. All other results presented here are from the November 1994 VSS sampling event.

Samples collected are thought to have been representative of the tank headspace when the tank was sampled (Meacham et al. 1995), and sample analyses were designed to provide a reasonably accurate and complete characterization of the significant headspace constituents. No assessment has been made of how the tank BY-111 headspace composition changes with time, though studies of tank C-103 suggest that composition changes probably occur very slowly in passively ventilated tanks, such as tank BY-111 (Huckaby and Story 1994).

\subsection{Tank Headspace Dynamics}

Tank BY-111 is the second tank in a 3-tank cascade with tanks BY-110 and BY-112. It is connected to tanks BY-110 and BY-112 via a 7.4-cm (2.9-in.) inside diameter, 7.6-m (25-ft) long underground cascade lines. Since these cascade lines connect the headspaces of these tanks, gases and vapors originating from the wastes in tank BY-110 or BY-112 may be transferred to tank BY-111 (unless the cascade lines are obstructed).

The cascade of tanks BY-110, BY-111, and BY-112 is passively ventilated, which means that the tanks are allowed to exhale air, waste gases, and vapors as the barometric pressure falls, and inhale ambient air as the barometric pressure rises. Each of these tanks has its own filtered breather riser. Barometric pressure typically rises and falis on a diurnal cycle, producing an average daily exchange of air equal to about $0.46 \%$ of each tank headspace (Huckaby 1994b). Changes in the concentrations of tank headspace constituents due to barometric pressure changes are consequently very slow. 


\subsection{SAMPLING EVENTS}

\subsection{May 1994 in Situ Sampling Event}

Tank BY-111 was sampled using ISS methods on May 11, 1994 by WHC Sampling and Mobile Laboratories. This sampling was conducted to satisfy requirements of Safety Assessment for Gas Sampling All Ferrocyanide Tanks (Farley 1991). Sorbent trap and SUMMATM canister samples were collected from a point approximately $6.7 \mathrm{~m}$ below the top of the flange on riser $12 \mathrm{~A}$, between 10:44 a.m. and 12:10 p.m. Though the sorbent traps were physically lowered down into the headspace to minimize loss of analytes through condensation, adsorption, or absorption by condensate, the SUMMA ${ }^{\text {TM }}$ canister samples were collected using unheated transfer tubing.

Huckaby et al. (1995) give a general description of the ISS method and equipment. Pingel (1994) provides field sampling information for the tank BY-111 May 1994 ISS event. In addition to the TNMOC measurement results presented below, McVeety et al. (1995a) and Rasmussen (1994) provide other sample analysis results.

\subsection{November 1994 Vapor Sampling System Sampling Event}

Headspace gas and vapor samples were collected from tank BY-111 using the VSS on November 16, 1994 by WHC Sampling and Mobile Laboratories (WHC 1995). Sample collection and analysis were performed as directed by Tank 241-BY-111 Tank Characterization Plan (TCP), (Homi 1994). The tank headspace temperature was determined to be $27^{\circ} \mathrm{C}$. Air from the tank BY-111 headspace was withdrawn via a $7.3 \mathrm{~m}$-long heated sampling probe mounted in riser $12 \mathrm{~A}$, and transferred via heated tubing to the VSS sampling manifold. All heated zones of the VSS were maintained at approximately $50^{\circ} \mathrm{C}$.

Sampling media were prepared and analyzed by WHC, Oak Ridge National Laboratories (ORNL), and Pacific Northwest Laboratories (PNL). The 32 tank air samples and 2 ambient air control samples collected are listed in Table 2-1 by analytical laboratory. Table 2-1 also lists the 13 trip blanks and 1 field blank that accompanied the samples.

A general description of vapor sampling and sample analysis methods is given by Huckaby and Babad (1995). The sampling equipment, sample collection sequence, sorbent trap sample air flow rates and flow times, chain of custody information, and a discussion of the sampling event itself are given in WHC (1995b). 


\subsection{INORGANIC GASES AND VAPORS}

Analytical results of sorbent trap and SUMMA ${ }^{T M, 1}$ canister tank air samples for selected inorganic gases and vapors are given in Table 3-1 in parts per million by volume (ppmv) in dry air. The concentration of water vapor given in Table 3-1 has been adjusted to tank conditions as given in Section 3.3. Inorganic analyte sorbent traps and SUMMA ${ }^{T M}$ canisters were prepared and analyzed by PNL at PNL quality assurance impact level 2 (Lucke et al. 1995a).

Analyses of the inorganic vapor sorbent traps were performed within 33 days of sample collection, analyses of SUMMA ${ }^{\text {TM }}$ canisters for inorganic compounds were performed 76 days after sample collection. Thus the 60-day holding time requirement of the WHC quality assurance project plan (Keller 1994) was satisfied for sorbent traps, but not for the SUMMA ${ }^{\mathrm{TM}}$ analyses. It should be noted that these inorganic compounds (i.e., the permanent gases) would be expected to be very stable in the SUMMA ${ }^{\mathrm{TM}}$ canisters, and the results may not have been affected even though the 60-day holding time requirements were exceeded.

\subsection{Ammonia, Hydrogen, and Nitrous Oxide}

Ammonia concentration in the headspace of tank BY-111 was measured at $59 \mathrm{ppmv}$. Ammonia has been observed in virtually all of the passively ventilated tanks sampled to date, at concentrations ranging from about 3 ppmv in tank C-108 (Lucke et al. 1995b), to 1040 ppmv in tank BY-108 (McVeety et al. 1995b). Given the LFL of ammonia in air is about $15 \%$ by volume (vol\%), the measured 59 ppmv corresponds to less than $0.04 \%$ of the LFL, and does not contribute appreciably to the flammability of the headspace.

Hydrogen was not detected in the SUMMA ${ }^{T M}$ canister samples, and determined to be present at $<160$ ppmv. In general, hydrogen is of concern as a fuel. The upper bound $160 \mathrm{ppmv}$ of hydrogen in tank BY111 , however, represents only about $0.4 \%$ of the LFL for hydrogen in air, and hydrogen would not be a flammability concern at this level.

Nitrous oxide was not detected in SUMMA ${ }^{\mathrm{TM}}$ canister samples either. Analyses indicated that nitrous oxide was present at $<67$ ppmv. Under proper conditions, nitrous oxide can serve as an oxidizer to support combustion. However, Cashdollar et al. (1992) found that nitrous oxide had no significant effect on the flammability of hydrogen and air mixtures for hydrogen concentrations less than 20 vol\%, and that "small amounts of nitrous oxide (relative to air) do not appear to have much effect on the flammability". Their results suggest the measured nitrous oxide concentration is much too low to have a significant effect on the flammability of the tank BY-111 headspace.

\subsection{Carbon Dioxide and Carbon Monoxide}

The average measured headspace carbon dioxide concentration, $219 \mathrm{ppmv}$, is significantly lower than the normal ambient air concentration of about 350 to $400 \mathrm{ppmv}$. Carbon dioxide introduced by air exchange with the atmosphere is readily absorbed by caustic supernatant and interstitial liquids of the waste tanks, and converted to carbonate in solution. It is reasonable to expect the level of carbon dioxide in a tank headspace will therefore depend on the tank's breathing rate, and the $\mathrm{pH}$ and surface area of aqueous waste (i.e., supernate, interstitial liquid, and condensate) in the tank. The 219 ppmv carbon dioxide concentration measured in tank BY- 111 is typical of other tanks sampled to date.

' SUMMA is a trademark of Molectrics, Inc., Cleveland, Ohio. 
Carbon monoxide in the tank BY-111 headspace was measured to be $<67$ ppmv. Elevated carbon monoxide concentrations have been observed in other waste tanks, and are thought to be due to the decomposition of organic waste in the tanks. The highest measured waste tank carbon monoxide concentration was [26.7 ppmv] in tank C-1032 (Huckaby and Story 1994).

\subsection{Nitric Oxide, Nitrogen Dioxide, Water and Tritium}

Nitric oxide and nitrogen dioxide concentrations in the tank BY-111 headspace were determined to be $s$ $0.15 \mathrm{ppmv}$ and $\leq 0.05 \mathrm{ppmv}$, respectively. These are both acid gases that would have very low equilibrium concentrations above the high pH waste in tank BY-111. Nitric oxide has been found at trace concentrations in other waste tanks, presumably due to its formation from oxygen and nitrogen in the radiation field of the headspace. These constituents could potentially serve as oxidizers to support combustion, but at the measured concentrations would have a negligible effect on the flammability of the tank BY-111 headspace.

The water vapor concentration of tank BY-111 was measured to be $6.9 \mathrm{mg} / \mathrm{L}$, at the tank headspace temperature of $27^{\circ} \mathrm{C}$ and pressure of $976 \mathrm{mbar}(732 \mathrm{torr})$, (WHC 1995b). This corresponds to a water vapor partial pressure of $9.6 \mathrm{mbar}(7.2 \mathrm{torr})$, to a dew point of $6.4^{\circ} \mathrm{C}$, and to a relative humidity of $27 \%$. This is a very low water vapor concentration compared to other waste tanks. Hanlon (1995) reports tank BY-111 has essentially no aqueous supernate; the low water vapor concentration may be indicative of the lack of free water near the waste surface in tank BY-111.

A test of the efficiency of the silica gel traps used to collect water vapor was performed during the tank BY111 sampling event (Lucke et al. 1995a). The test indicated that the normal sampling system trapped $96 \%$ of the total water vapor. The water vapor concentrations in Table 3-1 and discussed above have been corrected for the additional $4 \%$.

Tritium was tested for using silica gel sorbent traps. It is assumed that tritium ions produced by the waste combine with hydroxide ions to form tritium-substituted water. Evaporation of the tritium-substituted water would then result in airborne radioactive contamination. Silica gel sorbent traps adsorb virtually all (normal and tritium-substituted) water vapor from the sampled tank air, and are analyzed at the WHC 222-S laboratory. Analysis of the silica gel indicated the total activity of the sample to be below the method detection limit of $50 \mathrm{pCi} / \mathrm{L}$ (WHC 1995b).

\subsection{Discussion of Inorganic Gases and Vapors}

Aside from water vapor and carbon dioxide, the most abundant waste constituent in the tank BY-111 headspace is ammonia. The ammonia concentration is low compared to many other passively ventilated tanks that have been sampled, as are the hydrogen and nitrous oxide concentrations. These 3 constituents are usually the dominant species.

The relative standard deviations of the results, given in the last column in Table 3-1, are acceptible for the analytical methods used. Relative standard deviations range from $3 \%$ for ammonia, to $28 \%$ for carbon dioxide results. Poor precision is not a significant problem for the carbon dioxide measurements, because it is neither a flammability or industrial hygiene concern. The precision reported depends both on sampling parameters (e.g., sample flow rate and flow time for sorbent traps) and analytical parameters (e.g., sample

2 The carbon monoxide measurement in tank C-103 was made by Oregon Graduate Institute of Science and Technology, and placed in brackets to emphasize it should be considered secondary data. 


\section{WHC-SD-WM-ER-440 REV. 1}

preparation, dilutions, etc.), and the relative standard deviations suggest there were no significant problems in the field or in the laboratories.

As discussed briefly in Section 1.4, it is possible that gases and vapors generated by the waste in tanks BY110 and BY-112 could be transferred to tank BY-111 via the cascade lines. If significant exchange of selected inorganic gases and vapors were taking place between adjacent tanks, either their headspace compositions would be very similar, or all waste products detected in one tank would be at or equal or higher concentrations in the other tank. Table 3-2 lists selected inorganic compound concentrations for tanks BY-110, BY-111, and BY-112 for comparison. In this cascade of tanks there are no clear indications that gases and vapors are or are not being exchanged between the tanks. 


\subsection{ORGANIC VAPORS}

Organic vapors in the tank BY-111 headspace were sampled using SUMMATM canisters, which were analyzed at PNL, and triple sorbent traps (TSTs), which were analyzed by ORNL. Both laboratories used gas chromatographs (GCs) equipped with mass spectrometer (MS) detectors to separate, identify, and quantitate the analytes. Descriptions of sample device cleaning, sample preparations, and analyses are given by Jenkins et al. (1995a) and Lucke et al. (1995a). A quantitative measurement of the total organic vapor concentration by the U.S. Environmental Protection Agency (EPA) task order 12 (TO-12) method (EPA 1988) was also performed by Oregon Graduate Institute of Science and Technology (OGIST) on samples collected in May 1994 by the ISS method (Pingel 1994, Rasmussen 1994).

PNL SUMMA ${ }^{T M}$ sample results should be considered to be the primary organic vapor data for tank BY- 111. These results were produced at PNL quality assurance impact level 2. However, analyses of SUMMATM canisters for organic vapors were not completed until 80 days after sample collection, and this exceeded the administratively chosen 60-day holding time (Keller 1994). No holding time study has been performed to determine the stability of analytes in SUMMA ${ }^{\text {TM }}$ canisters in the chemical matrix of the tank samples.

ORNL analyses of TST samples from this and other waste tanks generally agree with, support, and augment the SUMMA ${ }^{T M}$ sample results. However, because certain WHC quality assurance requirements were not satisfied by ORNL, the quality assurance assessment of ORNL by Hendrickson (1995) should be reviewed before results unique to the TST samples are used for decision making.

All TSTs prepared by ORNL had 3 surrogate compounds added to evaluate sample matrix effects, potential handling, storage, and shipment problems, and analytical instrumentation performance (Jenkins et al. 1995a). ORNL evaluated the surrogate recoveries using a statistical approach similar to that prescribed by SW 846 Method 8260 A Volatile Organic Compounds by Gas ChromatographyMass Spectrometry (GCMS) Capillary Column Technique (EPA 1992). Using this approach, ORNL reported that all surrogates had standard deviation values within the $95 \%$ confidence interval for variance, indicating that no bias was introduced in the measurement of analyte quantities (Jenkins 1995a).

\subsection{Positively Identified Organic Analytes}

Positive identification of organic anaiytes using the methods employed by PNL and ORNL involves matching the GC retention times and MS data from a sample with that obtained by analysis of standards. The concentration of an analyte in the sample is said to be quantitatively measured if the response of the GC/MS has been established at several known concentrations of that analyte (i.e., the GCMS has been calibrated for that analyte), and the MS response to the analyte in the sample is between the lowest and highest responses to the known concentrations (i.e., the analyte is within the calibration range).

ORNL and PNL were assigned different lists of organic compounds, or target analytes, to positively identify and measure quantitatively. The ORNL target analyte list was derived from a review of the tank C-103 headspace constituents by a panel of toxicology experts (Mahlum et al. 1994). The PNL target analyte list included 39 compounds in the Environmental Protection Agency (EPA) task order 14 (TO-14) method, which are primarily halocarbons and common industrial solvents (EPA 1988), plus 14 analytes selected mainly from the toxicology panel's review of vapor data on tank C-103.

Listed in Table 4-1 are 5 organic compounds positively identified and quantitated in SUMMA ${ }^{\text {TM }}$ canister samples, and the methane analyses result. PNL performed analyses according to the EPA task order 14 (TO-14) methodology, but expanded the number of target analytes from 40 to 54 to include waste tank analytes of particular interest (EPA 1988, Lucke et al. 1995a). Methane was analyzed with the inorganic gases, because it is not analyzable by the TO-14 method. Of the original 40 TO-14 analytes, only 
trichlorofluoromethane was detected above the 0.002 ppmv quantitation limit, and only 4 of the 15 additional target analytes were above the 0.005 ppmv method quantitation limit. Averages reported are from analyses of 3 SUMMA ${ }^{\top M}$ canister samples.

ORNL positively identified 15 of 27 target analytes selected by WHC. Despite calibration of the instrument over about a 20-fold concentration range, only 3 of the positively identified compounds were within the instrument calibration range, and were quantitated. These are given with the 3-TST sample average concentration in Table 4-2. Table 4-3 lists 9 positively identified compounds for which the measurement in at least 1 of the TSTs was outside of the instrument calibration range, and consequently not quantitated. Table 4-4 lists the 3 remaining positively identified analytes, for which their analyte-specific ORNL practical holding time had been exceeded. Tables 4-2, 4-3, and 4-4 are mutually exclusive, so that no analyte appears in more than 1 of these tables. Data in Tables 4-3 and 4-4 should not be considered quantitative and may not be accurate to within $\pm 30 \%$ as specified by Burnum (1995).

Based on a practical holding time study performed by ORNL. the reported concentrations of propanone, butanal, and n-pentanenitrile may have been affected by the 61 day period between sample collection and analysis (Jenkins 1995b). The concentration of these 3 analytes are reported in Table 4-4. The practical holding time is defined as the holding time for which there is a $15 \%$ risk that the concentration of an analyte in the sample will be below its initial concentration. Jenkins ef al (1995b) describe the ORNL practical holding time study, and report practical holding times for these compounds.

Nine target analytes were common to both the ORNL. and PNL analyses. These are listed in Table 4-5 with the average concentrations reported by ORNL and PNL. Comparison of the results from the 2 laboratories indicates the following:

1) 2 of the analytes, vinylidene chloride and dichloromethane, were not detected in either sample type;

2) TST samples had 0.050 ppmv of ethanenitrile, but SUMMA ${ }^{\text {TM }}$ canister samples were found to have < 0.005 ppmv;

3) propanenitrile and $n$-butanenitrile were found to be $<0.005$ ppmv in both TST and SUMMATM samples; and

4) the 2 methods disagree on the concentrations propanone, n-hexane, benzene, $n$-heptane, and toluene.

Though the discrepancies between the TST and SUMMA ${ }^{T M}$ sample analyses are currently not understood, the reported concentrations are not above action limits. Furthermore, at the reported concentrations, the Table 4-1 analytes do not individually or cumulatively represent a flammability hazard.

\subsection{Tentatively Identified Organic Analytes}

In addition to the target analytes, the ORNL and PNL analytical procedures allow the tentative identification of other organic compounds. Tentative identification of analytes was performed by comparing the MS molecular fragmentation patterns with a library of known MS fragmentation patterns. This method allows an organic analyte to be identified (with reasonable certainty) as an alkane, a ketone, an aldehyde, etc., and may also determine its molecular weight. The method usually does not, however, allow the unambiguous identification of structural isomers, and this ambiguity increases with analyte molecular weight. Using this method, many analytes can be tentatively identified with reasonable confidence without having to inject each into the GC/MS to determine their GC retention times or specific MS patterns. 
By the nature of the sampling devices, virtually all organic vapors present in the tank headspace are collected by both TST and SUMMATM samples. Analyses of the samples are designed to recover, separate, and identify the organic vapors in the samples. TSTs are not good for collecting highly volatile compounds (i.e., molecules more volatile than propane), but are quite good for most others. In contrast, the recovery of very low volatility compounds (e.g., molecules with more than about 15 carbon atoms) and some polar compounds with moderate volatility (e.g., butanal) from SUMMA ${ }^{T M}$ samples has been problematic.

The organic compounds tentatively identified in SUMMA ${ }^{T M}$ canister samples by PNL are listed, with their estimated concentrations, in Table 4-6. Compounds are listed in Table 4-6 in the order by which they eluted chromatographically, and only non-zero results are included in the reported averages. The list of tentatively identified compounds detected in TST samples, and their estimated concentrations, is given in Table 4-7. Compounds are listed in Table 4-7 according to the order by which the eluted chromatographically. The averages reported by ORNL in Table 4-7 are all 3-sample averages, and if an analyte was not detected in a sample, its concentration in that sample was considered to be zero for averaging purposes. Estimated concentrations are in $\mathrm{mg} / \mathrm{m}^{3}$, based on dry air at $\theta^{\circ} \mathrm{C}$ and 1.01 bar.

The ORNL and PNL methods used to tentatively identify and estimate concentrations are described by Jenkins et al. (1995a) and Lucke et al. (1995a), respectively, and should be reviewed before this data are used for decision making. Concentrations given in Tables 4-6 and 4-7 should be considered rough estimates. The proper quantitation of all observed analytes is outside the scope and budget of these analyses, and the estimation of concentrations involves several important assumptions. The validity of each assumption depends on the analyte, and such factors as the specific configuration of the analytical instrumentation.

\subsection{Total Nonmethane Organic Carbon}

OGIST measured the TNMOC concentration in 3 SUMMA ${ }^{\text {TM }}$ canister samples collected on May 11, 1994 using the EPA TO-12 method (Rasmussen 1994). Because OGIST did not perform analyses with a WHCapproved quality assurance project plan in place, the OGIST results should be considered secondary data, and have been placed in brackets to emphasize this. The sample mean was $\left[9.6 \mathrm{mg} / \mathrm{m}^{3}\right]$, with a standard deviation of $\left[0.2 \mathrm{mg} / \mathrm{m}^{3}\right]$. MS analyses indicated only $2.2 \mathrm{mg} / \mathrm{m}^{3}$ of organic vapors in TST samples (Jenkins et al. 1995a).

\subsection{Discussion of Organic Analytes}

Some of the compounds listed in Tables 4-1 through 4-7 were introduced to the tank with process waste streams, and are detected in the headspace because the original inventory has not been completely evaporated or degraded. Examples of these are the semivolatile normal parafinic hydrocarbons (NPHs), (i.e., n-dodecane, n-tridecane, n-tetradecane, n-pentadecane) and methyl-substituted decahydronaphthalenes that were used as diluents for tributyl phosphate.

Though there is no toxicological or flammability hazard associated with the 0.13 ppmv of trichlorofluoromethane measured in tank BY-111, its presence has been noted in many of the tanks sampled to date. The origin of trichlorofluoromethane in the waste tanks has not been established, however, it may be present from its use in urethane foam that were applied to concrete tank pits as a sealant.

Most of the compounds in Tables 4-1 through 4-7 are believed to be chemical reaction and radiolytic reaction products of the semivolatile or nonvolatile organic waste stored in the tank. For example, 1- 
butanol is known to be formed by the hydrolysis of tributyl phosphate, and it has been suggested that the alcohols, aldehydes, ketones, nitriles, alkenes, and short chain alkanes are all degradation products of NPHs.

Neither TST nor SUMMATM methods detected tributyl phosphate as a headspace constituent. The relatively high concentration of 1-butanol, however, is a strong indication that tributyl phosphate does exist in tank BY111. That tributyl phosphate was not observed in the TST samples may be due to the facts that tributyl phosphate has a very low vapor pressure, and it has a tendency to adsorb on to the high efficiency particulate air filters used during sampling to protect the samples from radiological particulate contamination.

In general, the character of organic vapors in tank BY-111 appears to be very similar to other NPH-rich waste tanks in 241-C and 241-BY farms. As indicated in Table 3-2, tank BY-111 has the lowest levels of organic vapors in the tank BY-110, BY-111, and BY-112 cascade. 


\section{WHC-SD-WM-ER-440 REV. 1}

\subsection{SUMMARY}

The tank BY-111 headspace was sampled in May 1994 and November 1994 for gases and vapors to address flammability and industrial hygiene concerns. Results unique to the May 1994 event and essentially all results from the November 1994 event have been reported. It was determined that no headspace constituents exceeded the flammability or industrial hygiene notification limits specified in the current Vapor Sampling and Analysis Plan (Homi 1995). 


\subsection{REFERENCES}

29 CFR 1910.120, 1993, "Hazardous Waste Operations and Emergency Response", Code of Federal Regulations.

Burnum, S. T., 1995, Qualiiication of Reported WHC Vapor Program Data, (letter 95-CHD-065 to president, Westinghouse Hanford Company, August 18), Department of Energy, Richland Operations Office, Richland, Washington.

Cashdollar, K. L..,M. Hertzberg, I. A. Zlochower, C. E. Lucci, G. M. Green, and R. A. Thomas, 1992, Laboratory Flammability Studies of Mixtures of Hydrogen, Nitrous Oxide, and Air, WHC-SD-WMES-219 Rev. 0, Westinghouse Hanford Company, Richland, Washington.

Dougherty, L. F., 1995, Single Shell Tank Interim Operational Safety Requirements, WHC-SD-WM-OSR005 Rev. 0, Westinghouse Hanford Company, Richland, Washington.

EPA 1988, Compendium of Methods for the Determination of Toxic Organic Compounds in Ambient Air, PB90-127374, U.S. Environmental Protection Agency, Washington, D.C.

EPA 1992, Test Methods for Evaluating Solid Waste, SW-846 Rev. 1, U.S. Environmental Protection Agency, Washington, D.C.

Farley, W. G., 1991, Safety Assessment for Gas Sampling All Ferrocyanide Tanks, WHC-SD-WM-SAD-009 Rev. 2, Westinghouse Hanford Company, Richland, Washington.

Hanlon, B. M., 1995, Waste Tank Summary for Month Ending December 31, 1994, WHC-EP-0182-81, Westinghouse Hanford Company, Richland, Washington.

Hendrickson, R. W., 1995, Tank Vapor Characterization Oak Ridge National Laboratories Quality Assurance Assessment, TWRSQA-95-0012, Westinghouse Hanford Company, Fichland, Washington.

Homi, C. S., 1994, Tank 241-BY-111 Tank Characterization Plan, WHC-SD-WM-TP-280 Rev OA, Westinghouse Hanford Company, Richland, Washington.

Homi, C. S., 1995, Vapor Sampling and Analysis Plan, WHC-SD-WM-TP-335 Rev. 0G, Westinghouse Hanford Company, Richland, Washington.

Huckaby, J. L., 1994a, Vapor Sampling System (VSS) and in Situ Sampling (ISS) Method Comparison, WHC-SD-WM-RPT-101 Rev. 0, Westinghouse Hanford Company, Richland, Washington.

Huckaby, J. L., 1994b, Tank 241-C-103 Headspace Flammability, WHC-EP-0734 Rev. 1, Westinghouse Hanford Company, Richland, Washington.

Huckaby, J. L., H. Babad, and D. R. Bratzel, 1995, Headspace Gas and Vapor Characterization Summary for the 43 Vapor Program Suspect Tanks, WHC-SD-WM-ER-514 Rev. 0, Westinghouse Hanford Company, Richland, Washington.

Huckaby, J. L., and D. R. Bratzel, 1995a, Tank 241-BY-110 Headspace Gas and Vapor Characterization Results for Samples Collected in November 1994, WHC-SD-WM-ER-429 Rev. 2, Westinghouse Hanford Company, Richland, Washington. 


\section{WHC-SD-WM-ER-440 REV. 1}

Huckaby, J. L., and D. R. Bratzel, 1995b, Tank 241-BY-112, Headspace Gas and Vapor Characterization Results for Samples Collected in November 1994, WHC-SD-WM-ER-441 Rev. 1, Westinghouse Hanford Company, Richland, Washington.

Huckaby, J. L., and M. S. Story, 1994, Vapor Characterization of Tank 241-C-103, WHC-EP-0780 Rev. 0, Westinghouse Hanford Company, Richland, Washington.

Jenkins, R. A., 1995a, Untitled, (Letter 090195A to D. Bratzel, September 1), Oak Ridge National Laboratory, Oak Ridge, Tennessee

Jenkins, R. A., 1995b, Untitled, (Letter 091495A to D. Bratzel, September 14), Oak Ridge National Laboratory, Oak Ridge, Tennessee.

Jenkins, R. A, A. B. Dindal, C. E. Higgins, C. Y. Ma, M. A. Palausky, J. T. Skeen, and C. K. Bayne, 1995a, Analysis of Tank 241-BY-111 Headspace Components, ORNL-CASD-FR-241BY111.95, Rev. 0, Oak Ridge National Laboratory, Oak Ridge, Tennessee.

Jenkins, R. A, A. B. Dindal, C. Y. Ma, M. A. Palausky, J. T. Skeen, and C. K. Bayne, 1995b, Analysis of Tank 241-TY-104 Headspace Components, ORNL-CASD-FR-241TY104.95 Rev. 1, Oak Ridge National Laboratory, Oak Ridge, Tennessee.

Keller, K.K., 1994, Quality Assurance Project Plan for Tank Vapor Characterization, WHC-SD-WM-QAPP013 Rev.2, Westinghouse Hanford Company, Richland, Washington.

Ligotke, M. W. 1995, PNL Vapor Project Analytical Holding Times, (Letter to D.R. Bratzel, September 23, 1995), Pacific Northwest Laboratory, Richland, Washington.

Ligotke, M. W., K. H. Pool, T. W. Clauss, B. D. MoVeety, G. S. Klinger, K. B. Olsen, O. P. Bredt, J. S. Fruchter, and S. C. Goheen, 1995, Vapor Space Characterization of Waste Tank 241-U-103: Results from Samples Collected on 2/15/95, PNL-10813 UC-606, Pacific Northwest Laboratory, Richland, Washington.

Lucke, R. B., T. W. Clauss, M. W. Ligotke, K. H. Pool, B. D. MóVeety, G. S. Klinger, J. S. Young, M. McCulloch, J. S. Fruchter, and S. C. Goheen, 1995a, Vapor Space Characterization of Waste Tank 241-BY-111: Results from Samples Collected Through the Vapor Sampling System on 11/16/94, PNL-10599 UC-606, Pacific Northwest Laboratory, Richland, Washington.

Lucke, R. B., M. W. Ligotke, K. H. Pool, T. W. Clauss, A. K. Sharma, B. D. McVeety, M. McCulloch, J. S. Fruchter, and S. C. Goheen, 1995b, Vapor Space Characterization of Waste Tank 241-C-108: Results from Samples Collected Through the Vapor Sampling System on 8/5/94, PNL-10351 UC. 606, Pacific Northwest Laboratory, Richland, Washington.

Mahon, R., 1995, FY 1994 in-Situ Sampling System Summary Report, (Letter OM624-95-055 to D. Bratzel), Westinghouse Hanford Company, Richland, Washington.

Mahlum, D. D., J. Y. Young, and R. E. Weller, 1994, Toxicologic Evaluation of Analytes from Tank 231-C103, PNL-10189, Pacific Northwest Laboratory, Richland, Washington. 


\section{WHC-SD-WM-ER-440 REV. 1}

McVeety, B. D., T. W. Clauss, M. W. Ligotke, K. H. Pool, R. B. Lucke, A. K. Sharma, M. McCulloch, J. S. Fruchter, and S. C. Goheen, 1995a, Vapor Space Characterization of Waste Tank 241-BY-111 in Situ): Results from Samples Collected on 5/11/94, PNL-10368 UC-606, Pacific Northwest Laboratory, Richland, Washington.

McVeety, B. D., T. W. Clauss, M. W. Ligotke, K. H. Pool, R. B. Lucke, G. S. Klinger, J. S. Young, M. McCulloch, J. S. Fruchter, and S. C. Goheen, 1995b, Vapor Space Characterization of Waste Tank 241-BY-108: Results from Samples Collected on 10/27/94, PNL-10495 UC-606, Pacific Northwest Laboratory, Richland, Washington.

Meacham, J. E., H. Babad, R. J. Cash, G. T. Dukelow, S. J. Eberlein, D. W. Hamilton, G. D. Johnson, J. W. Osborne, M. A. Payne, D. J. Sherwood, D. A. Turner, and J. L. Huckaby, 1995, Approach for Tank Safety Characterization of Hanford Site Waste, WHC-EP-0843 Rev. 0, UC-2070, Westinghouse Hanford Company, Richland, Washington.

NFPA 1992, Standard on Explosion Prevention Systems, NFPA 69, National Fire Protection Association, Quincy, Massachusetts.

Osborne, J. W., and J. L. Huckaby, 1994, Program Plan for the Resolution of Tank Vapor /ssues, WHC-EP0562 Rev. 1, Westinghouse Hanford Company, Richland, Washington.

Osborne, J. W., J. L. Huckaby, T. P. Rudoiph, E. R. Hewitt, D. D. Mahlum, J. Y. Young, and C. M. Anderson, 1994, Data Quality Objectives for Generic In-Tank Health and Safety Issue Resolution, WHC-SD-WM-DQO-002, Westinghouse Hanford Company, Richland, Washington.

Pingel, L. A., 1994, Results from the In-Situ Vapor Sampling of Waste Tank BY-111, (Internal memorandum 8E920-SAS94-092 to J. L. Huckaby, May 26), Westinghouse Hanford Company, Richland, Washington.

Rasmussen, R. A., 1994, Air Samples Collected at Waste Tanks: BY-103 on 5-5-94; BY-104 on 4-28-94; $B Y-105$ on $5-9-94 ; B Y-106$ on 5-4-94; BY-111 on 5-11/94 by Westinghouse Hanford in $6-L S S$ SUMMA@ Canisters, Oregon Graduate Institute of Science and Technology, Beaverton, Oregon.

WHC 1995a, Operating Specifications for Watchlist Tanks, OSD-T-151-00030, Rev. B-9, Westinghouse Hanford Company, Richland, Washington.

WHC 1995b, Vapor and Gas Sampling of Single-Shell Tank 241-BY-111 Using the Vapor Sampling System, WHC-SD-WM-RPT-124, Westinghouse Hanford Company, Richland, Washington. 


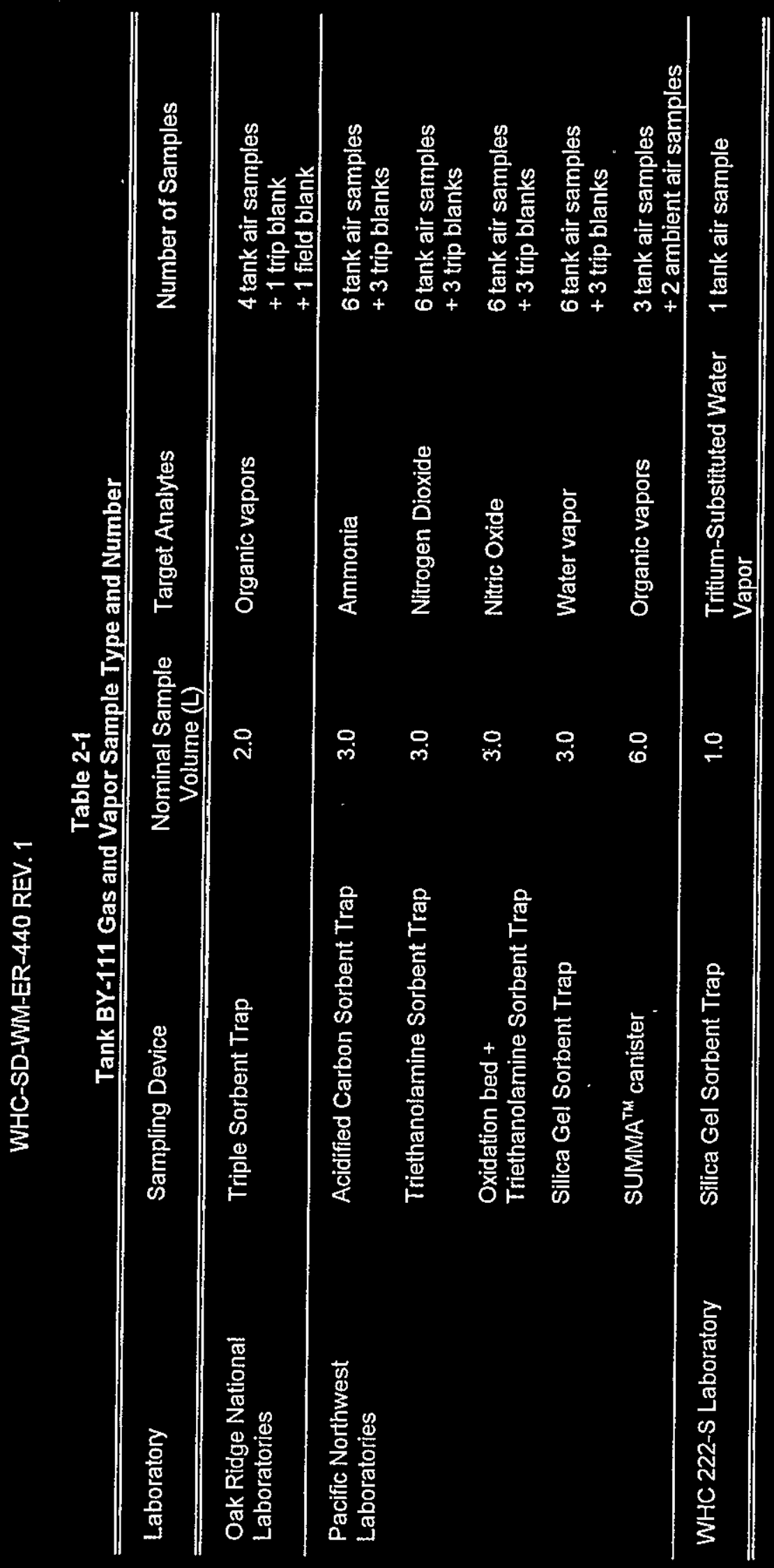




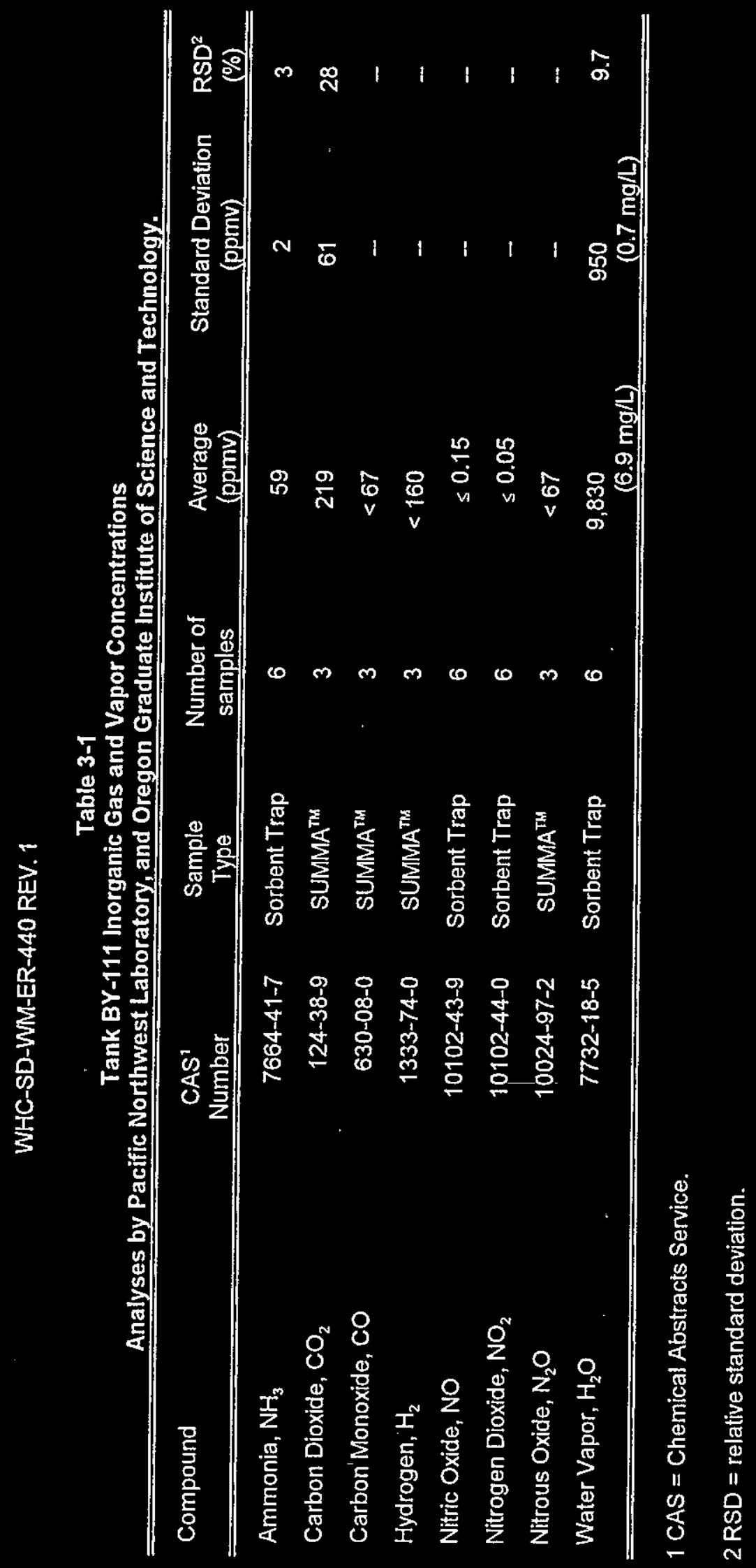


Table 3-2

Comparison of Tank BY-110, BY-111, and BY-112 Headspace Constituents ${ }^{1}$

\begin{tabular}{|c|c|c|c|}
\hline Tank: & $B Y-110^{2}$ & BY-111 & $\mathrm{BY}-112^{3}$ \\
\hline Date sampled, (mo/day/yr) & $11 / 11 / 94$ & $\begin{array}{c}5 / 11 / 94 \\
11 / 16 / 94 \\
\end{array}$ & $11 / 18 / 94$ \\
\hline Headspace temperature, $\left({ }^{\circ} \mathrm{C}\right)$ & 27 & 27 & 23.2 \\
\hline Ammonia, (ppmv) & 401 & 59 & 63 \\
\hline Hydrogen, (ppmv) & $<160$ & $<160$ & $<94$ \\
\hline Carbon dioxide, (ppmv) & 229 & 219 & 121 \\
\hline Carbon monoxide, (ppmv) & $<76$ & $<76$ & $<12$ \\
\hline Nitric oxide, (ppmv) & $=0.09$ & $=0.15$ & 0.18 \\
\hline Nitrogen dioxide, (ppmv) & $=0.05$ & $\therefore 0.05$ & $s 0.02$ \\
\hline Nitrous oxide, (ppmv) & 103 & $<67$ & 40 \\
\hline Water vapor, $\left(\mathrm{mg} / \mathrm{m}^{3}\right)$ & 8.0 & 6.9 & 11.2 \\
\hline Water vapor, (\% relative humidity) & 31 & 27 & 53 \\
\hline Ethanenitrile (acetonitrile), (ppmv) & 0.81 & 0.050 & 0.10 \\
\hline Propanone (acetone), (ppmv) & $(3.8)$ & $(0.48)$ & $(1.0)$ \\
\hline 1-Butanol, (ppmv) & 0.30 & $<0.0011$ & 0.059 \\
\hline n-Dodecane, (ppmv) & 0.079 & $<0.00046$ & 0.0097 \\
\hline $\mathrm{n}$-Tridecane, (ppmv) & 0.13 & $(0.0015)$ & 0.020 \\
\hline Total organic compounds ${ }^{4},\left(\mathrm{mg} / \mathrm{m}^{3}\right)$ & 29 & 2.2 & 5.8 \\
\hline
\end{tabular}

1 Inorganic gas or vapor results are from PNL; organic vapor results are from ORNL, with semiquantitative values in parentheses and quantitative values not in parentheses.

2 Data are from Huckaby and Bratzel 1995a.

3 Data are from Huckaby and Bratzel 1995b.

4 Total organic compound concentration was estimated from TST sample results. 
WHC-SD-WM-ER-440 REV. 1

Table 4-1

Tank BY-111 Quantitatively Measured Organic Compounds in SUMMA ${ }^{\text {TM }}$ Samples -Analyses by Pacific Northwest Laboratory

\begin{tabular}{clcccc}
\hline $\begin{array}{c}\text { Cmpd } \\
\#\end{array}$ & Compound & $\begin{array}{c}\mathrm{CAS}^{1} \\
\text { Number }\end{array}$ & $\begin{array}{c}\text { Average } \\
(\mathrm{ppmv})\end{array}$ & $\begin{array}{c}\text { Standard } \\
\text { Deviation } \\
\text { (ppmv) }\end{array}$ & $\begin{array}{c}\mathrm{RSD}^{3} \\
(\%)\end{array}$ \\
\hline \hline 1 & Trichlorofluoromethane & $75-69-4$ & 0.129 & 0.007 & 6 \\
2 & Propanone (acetone) & $67-64-1$ & 1.55 & 0.10 & 6 \\
3 & 2-Butanone & $78-93-3$ & 0.106 & 0.003 & 3 \\
4 & n-Heptane & $142-82-5$ & 0.040 & 0.001 & 15 \\
5 & Toluene & $108-88-3$ & 0.044 & 0.003 & 6 \\
6 & Methane & $74-82-8$ & $<61$ & - & - \\
\hline \hline
\end{tabular}

$1 \mathrm{CAS}=$ Chemical Abstract Service.

2 Average of 3 samples.

3 RSD = relative standard deviation. Burnum (1995) specifies the RSD should be less than $25 \%$. 
WHC-SD-WM-ER-440 REV. 1

Table 4-2

Tank BY-111 Quantitatively Measured Organic Compounds in TST Samples -Analyses by Oak Ridge National Laboratory ${ }^{1}$

\begin{tabular}{clrrrr}
\hline $\begin{array}{c}\text { Cmpd } \\
\#\end{array}$ & Compound & $\begin{array}{c}\mathrm{CAS}^{2} \\
\text { Number }\end{array}$ & $\begin{array}{c}\text { Average } \\
\text { (ppmv) }\end{array}$ & $\begin{array}{c}\text { Standard } \\
\text { Deviation } \\
(\mathrm{ppmV})\end{array}$ & $\begin{array}{c}\mathrm{RSD}^{4} \\
(\%)\end{array}$ \\
\hline 1 & Ethanenitrile (acetonitrile) & $75-05-8$ & 0.050 & 0.003 & 5 \\
2 & n-Hexane & $110-54-3$ & 0.011 & 0.002 & 20 \\
3 & Benzene & $71-43-2$ & 0.011 & 0.003 & 31 \\
\hline \hline
\end{tabular}

1 Results in this table are quantitative (as defined in Section 4.1).

$2 \mathrm{CAS}=$ Chemical Abstract Service.

3 Average of 3, 2-L TST samples.

$4 \mathrm{RSD}=$ relative standard deviation. Burnum (1995) specifies the RSD should be less than $25 \%$. 
Table 4-3

Tank BY-111 Positively Identified Organic Compounds in TST Samples Analyses by Oak Ridge National Laboratory

\begin{tabular}{clcccc}
\hline $\begin{array}{c}\text { Cmpd } \\
\#\end{array}$ & Compound & $\begin{array}{c}\text { CAS }^{2} \\
\text { Number }\end{array}$ & $\begin{array}{c}\text { Average } \\
(\mathrm{ppmv})\end{array}$ & $\begin{array}{c}\text { Standard } \\
\text { Deviation } \\
\text { (ppmV) }\end{array}$ & $\begin{array}{c}\text { RSD }^{4} \\
(\%)\end{array}$ \\
\hline 1 & Propanenitrile & $107-12-0$ & 0.0021 & 0.0002 & 8 \\
2 & Butanenitrile & $109-74-0$ & 0.0024 & 0.0004 & 18 \\
3 & n-Heptane & $142-82-5$ & 0.0017 & 0.0004 & 26 \\
4 & Toluene & $108-88-3$ & 0.0031 & 0.0011 & 35 \\
5 & n-Octane & $111-65-9$ & $<0.0002$ & - & - \\
6 & n-Nonane & $111-84-2$ & 0.00017 & 0.00001 & 7 \\
7 & n-Undecane & $1120-21-4$ & $<0.00032$ & - & - \\
8 & n-Dodecane & $112-40-3$ & $<0.00046$ & - & - \\
9 & n-Tridecane & $629-50-5$ & 0.0015 & 0.0015 & 18 \\
\hline \hline
\end{tabular}

1 Results in this table are not quantitative (as defined in Section 4.1) because measured values in at least 1 of the samples are outside instrument calibration limits.

$2 \mathrm{CAS}=$ Chemical Abstract Service.

3 Average of 3, 2-L TST samples.

4 RSD = relative standard deviation, Burnum (1995) specifies the RSD should be less than $25 \%$. 
WHC-SD-WM-ER-440 REV. 1

Table 4-4

Tank BY-111 Positively ldentified Organic Compounds in TST Samples for which Practical Holding Times were Exceeded -Analyses by Oak Ridge National Laboratory'

\begin{tabular}{|c|c|c|c|c|c|}
\hline$\underset{\#}{\text { Cmpd }}$ & Compound & $\begin{array}{c}\mathrm{CAS}^{2} \\
\text { Number }\end{array}$ & $\begin{array}{c}\text { Average }^{3} \\
\text { (ppmv) }\end{array}$ & $\begin{array}{c}\text { Standard } \\
\text { Deviation } \\
\text { (ppmv) }\end{array}$ & $\begin{array}{c}\mathrm{RSD}^{4} \\
(\%)\end{array}$ \\
\hline 1 & Propanone (acetone) ${ }^{5}$ & $67-64-1$ & 0.48 & 0.02 & 3 \\
\hline 2 & Butanal $\left.\right|^{5}$ & $123-72-8$ & 0.0026 & 0.0005 & 20 \\
\hline 3 & Pentanenitrile ${ }^{5}$ & $110-59-8$ & $<0.00042$ & 0.00014 & 33 \\
\hline
\end{tabular}

1 Practical holding times are defined and discussed in Section 4.1.

$2 \mathrm{CAS}=$ Chemical Abstract Service.

3 Average of 3, 2-L TST samples.

$4 \mathrm{RSD}=$ relative standard deviation. Burnum (1995) specifies the RSD should be less than $25 \%$.

5 The concentration of this analyte was not quantitatively measured (as defined in Section 4.1), because the measured concentration was outside of the instrumental calibration limits. 


\section{WHC-SD-WM-ER-440 REV. 1}

Table 4-5

Tank BY-111 Comparison of Organic Compounds in TST and SUMMA ${ }^{\text {TM }}$ Samples-m Analyses by Pacific Northwest Laboratory and Oak Ridge National Laboratory

\begin{tabular}{lcccc}
\hline Compound & $\begin{array}{c}\text { CAS }^{1} \\
\text { Number }\end{array}$ & $\begin{array}{c}\text { TST } \\
\text { Average } \\
\text { (ppmv) }\end{array}$ & $\begin{array}{c}\text { SUMMA }^{\text {SM }} \\
\text { Average }^{3} \\
\text { (ppmv) }\end{array}$ & $\begin{array}{c}\text { PRD }^{4} \\
(\%)\end{array}$ \\
\hline \hline Ethanenitrile (acetonitrile) & $75-05-8$ & 0.050 & $<0.005$ & $>164$ \\
Propanone (acetone) & $67-64-1$ & 0.48 & 1.55 & 105 \\
Propanenitrile & $107-12-0$ & 0.0021 & $<0.005$ & - \\
n-Hexane & $110-54-3$ & 0.011 & $<0.005$ & $>75$ \\
Benzene & $71-43-2$ & 0.011 & $<0.005$ & $>75$ \\
Butanenitrile & $109-74-0$ & 0.0024 & $<0.005$ & - \\
n-Heptane & $142-82-5$ & 0.0017 & 0.040 & 184 \\
Toluene & $108-88-3$ & 0.0031 & 0.044 & 174 \\
Pentanenitrile & $110-59-8$ & $<0.00042$ & $<0.005$ & - \\
\hline \hline
\end{tabular}

$1 \mathrm{CAS}=$ Chemical Abstract Service.

2 Average of 3, 2-L. TST samples.

3 Average of 3 samples from PNL.

$4 \mathrm{PRD}=$ percent relative difference. Keller (1994) requires the PRD to be less than $20 \%$. 
WHC-SD-WM-ER-440 REV. 1

Table 4-6

Tank BY-111 Tentatively Identified Organic Compounds in SUMMA' ${ }^{\text {TM }}$ Samples Analyses by Pacific Northwest Laboratory

\begin{tabular}{|c|c|c|c|c|}
\hline$\underset{\#}{C m p d}$ & Compound & $\begin{array}{l}\mathrm{CAS}^{1} \\
\text { Number }\end{array}$ & $\begin{array}{l}\text { Average }^{5} \\
\left(\mathrm{mg} / \mathrm{m}^{3}\right)\end{array}$ & $\begin{array}{c}\text { Standard } \\
\text { Deviation } \\
\left(\mathrm{mg} / \mathrm{m}^{3}\right)\end{array}$ \\
\hline 1 & Propene & $115-07-1$ & 0.23 & 0.04 \\
\hline 2 & Propane & $74-98-6$ & 0.19 & 0.05 \\
\hline 3 & Cyclopropane & $75-19-4$ & 0.12 & 0.01 \\
\hline 4 & Isobutane & $75-28-5$ & 0.18 & 0.01 \\
\hline 5 & 1-Butene & $106-98-9$ & 0.07 & 0.00 \\
\hline 6 & Butane & $106-97-8$ & 0.18 & 0.02 \\
\hline 7 & 2-Methyl-1-propene ${ }^{3}$ & $115-11-7$ & 0.06 & - \\
\hline 8 & Ethanol & $64-17-5$ & 0.07 & 0.00 \\
\hline 9 & Pentane & $109-66-0$ & 0.28 & 0.03 \\
\hline 10 & 2-Methyl-2-propanol & $75-65-0$ & 0.15 & 0.01 \\
\hline 11 & 2-Methyl-pentane & $107-83-5$ & 0.11 & 0.01 \\
\hline 12 & Butanal $^{4}$ & $123-72-8$ & 0.06 & 0.01 \\
\hline 13 & 1-Butanol & $71-36-3$ & 0.17 & 0.00 \\
\hline 14 & 2-Pentanone ${ }^{4}$ & $107-87-9$ & 0.16 & $<0.01$ \\
\hline 15 & Cyclopentanol & $96-41-3$ & 0.06 & $<0.01$ \\
\hline 16 & Cyclopentanol & $96-41-3$ & 0.06 & $<0.01$ \\
\hline 17 & 2-Hexanone & $591-78-6$ & 0.08 & $<0.01$ \\
\hline 18 & Octane & $111-65-9$ & 0.06 & $<0.01$ \\
\hline 19 & 3-Heptanone & $106-35-4$ & 0.18 & 0.01 \\
\hline 21 & 2-Heptanone ${ }^{4}$ & $110-43-0$ & 0.07 & $<0.01$ \\
\hline 22 & Unknown Ketone $^{3}$ & & 0.07 & - \\
\hline 24 & Undecane & $1120-21-4$ & 0.07 & 0.00 \\
\hline 25 & Dodecane & $112-40-3$ & 0.09 & 0.00 \\
\hline 26 & Tridecane & $629-50-5$ & 0.07 & $\underline{0.01}$ \\
\hline \multicolumn{3}{|c|}{ Sum of tentatively identified compounds: } & 2.84 & \\
\hline
\end{tabular}

$1 \mathrm{CAS}=$ Chemical Abstract Service. 
2 When the analyte was detected in only 2 samples, the entry is the relative difference (i.e., their difference divided by 2).

3 Detected in only 1 sample.

4 Detected in only 2 samples.

5 Average of 3 samples, values listed are estimates. 


\section{WHC-SD-WM-ER-440 REV. 1}

Table 4-7

Tank BY-111 Tentatively Identified Organic Compounds in TST Samples Analyses by Oak Ridge National Laboratory

\begin{tabular}{|c|c|c|c|c|}
\hline$\underset{\#}{\text { Cmpd }}$ & Compound & $\begin{array}{c}\text { CAS }^{1} \\
\text { Number }\end{array}$ & $\begin{array}{c}\text { Average }^{2} \\
\left(\mathrm{mg} / \mathrm{m}^{3}\right)\end{array}$ & $\begin{array}{c}\text { Standard } \\
\text { Deviation } \\
\left(\mathrm{mg} / \mathrm{m}^{3}\right)\end{array}$ \\
\hline 1 & Cyclopropane & $75-19-4$ & 0.0120 & 0.00163 \\
\hline 2 & Isobutane & $75-28-5$ & 0.0158 & 0.00337 \\
\hline 3 & 1-Propene, 2-methyl- & $115-11-7$ & 0.0804 & 0.00591 \\
\hline 4 & Butane & $106-97-8$ & 0.1851 & 0.03169 \\
\hline 5 & 1-Butene & $106-98-9$ & 0.0229 & 0.00217 \\
\hline 6 & Cyclobutane & $287-23-0$ & 0.0165 & 0.00202 \\
\hline 7 & Butane, 2-methyl- \& Ethanol & & 0.0555 & 0.00860 \\
\hline 8 & Trichloromonofluoromethane & $75-69-4$ & 0.1117 & 0.00342 \\
\hline 9 & 1-Pentene & $109-67-1$ & 0.0125 & 0.00195 \\
\hline 10 & 1,3-Butadiene, 2-methyl- & $78-79-5$ & 0.0089 & 0.00225 \\
\hline 11 & Isopropyl alcohol & $67-63-0$ & 0.0087 & 0.00798 \\
\hline 12 & 2-Butene, 2-methyl- & $513-35-9$ & 0.0019 & 0.00326 \\
\hline 13 & 1-Pentene & $109-67-1$ & 0.0056 & 0.00485 \\
\hline 14 & Butane, 2,2-dimethyl- & $75-83-2$ & 0.0077 & 0.00095 \\
\hline 15 & Pentane, 2-methyl- & $107-83-5$ & 0.0308 & 0.00484 \\
\hline 16 & 2-Propenal, 2-methyl- & $78-85-3$ & 0.0024 & 0.00409 \\
\hline 17 & 1-Propanol & $71-23-8$ & 0.0024 & 0.00409 \\
\hline 18 & Pentane, 3-methyl- & $96-14-0$ & 0.0082 & 0.00082 \\
\hline 19 & 1-Hexene & $592-41-6$ & 0.0054 & 0.00472 \\
\hline 20 & 3-Buten-2-one & $78-94-4$ & 0.0061 & 0.00568 \\
\hline 21 & Propanal, 2-methyl- & $78-84-2$ & 0.0019 & 0.00322 \\
\hline 22 & Furan, tetrahydro- & $109-99-9$ & 0.0075 & 0.00111 \\
\hline 23 & Hexane, 3-methyl- & $589-34-4$ & 0.0054 & 0.00475 \\
\hline 24 & 2-Butanone, 3,3-dimethyl- & $75-97-8$ & 0.0189 & 0.00102 \\
\hline 25 & 2-Pentanone, 4,4-dimethyl- & $590-50-1$ & 0.0076 & 0.00161 \\
\hline 26 & Cyclohexane, 1,1,3-trimethyl- & $3073-66-3$ & 0.0014 & 0.00237 \\
\hline 27 & $\begin{array}{l}\text { Cyclotetrasiloxane, } \\
\text { octamethyl- }\end{array}$ & $556-67-2$ & 0.0031 & 0.00281 \\
\hline
\end{tabular}


WHC-SD-WM-ER-440 REV. 1

\begin{tabular}{|c|c|c|c|c|}
\hline$\underset{\#}{\text { Cmpd }}$ & Compound & $\begin{array}{c}\text { CAS }^{\prime} \\
\text { Number }\end{array}$ & $\begin{array}{l}\text { Average }^{2} \\
\left(\mathrm{mg} / \mathrm{m}^{3}\right)\end{array}$ & $\begin{array}{c}\text { Standard } \\
\text { Deviation } \\
\left(\mathrm{mg} / \mathrm{m}^{3}\right)\end{array}$ \\
\hline 28 & $\begin{array}{l}\text { Naphthalene, } \\
\text { decahydro-2-methyl- }\end{array}$ & $2958-76-1$ & 0.0014 & 0.00244 \\
\hline 29 & $\begin{array}{l}\text { Cyclohexane, } \\
\text { 2-butyl-1,1,3-trimethyl- }\end{array}$ & $54676-39-0$ & 0.0108 & 0.00221 \\
\hline 30 & Methenamine & $100-97-0$ & 0.0316 & 0.01372 \\
\hline 31 & $\begin{array}{l}\text { Cyclohexane, } \\
\text { 1,3,5-trimethyl-2-octadecyl- }\end{array}$ & $55282-34-3$ & 0.0026 & 0.00231 \\
\hline 32 & $\begin{array}{l}\text { 2(3H)-Benzofuranone, } \\
3 \mathrm{a}, 4,5,6 \text {-tetra- }\end{array}$ & $16778-26-0$ & 0.0034 & 0.00291 \\
\hline 33 & $\begin{array}{l}\text { Cyclohexane, } \\
\text { 1-(cyclohexylmethyl)2-ethyl- }\end{array}$ & $54934-93-9$ & 0.0056 & 0.00171 \\
\hline 34 & Benzenesulfonamide, N-butyl- & $3622-84-2$ & 0.0161 & 0.00967 \\
\hline 35 & Eicosane & $112-95-8$ & 0.0226 & 0.02784 \\
\hline 36 & Isopropyl Palmitate & $142-91-6$ & 0.0017 & 0.00303 \\
\hline 37. & Hexadecanal & $629-80-1$ & 0.0016 & 0.00271 \\
\hline \multicolumn{3}{|c|}{ Sum of tentatively identified compounds: } & 0.74 & \\
\hline
\end{tabular}

$1 \mathrm{CAS}=$ Chemical Abstract Service.

2 Average of 3, 2-L TST samples, values listed are estimates. 